811.163.41'38:929 Ковачевић М. https://doi.org/10.18485/sj.2019.24.1.3

ДУШАН Р. ЖИВКОВИТ *

Универзитет у Крагујевцу

Филолошко-уметнички факултет
Оригинални научни рад Примљен: 09. 10. 2018. Прихваћен: 15. 01. 2019.

\title{
НАУЧНИ ЗНАЧАЈИ И ДОМИНАНТНИ ИНТЕРТЕКСТУАЛНИ АСПЕКТИ ЛИНГВОСТИЛИСТИКЕ КЊИЖЕВНОГ ТЕКСТА МИЛОША КОВАЧЕВИЋА**
}

Предмет овог рада представља анализу научног значаја и доминантних интертекстуалних аспеката Лингвостилистике књижевног текста Милоша Ковачевића. Први део рада посвећен је општим аспектима у контексту односа светских филолошких токова и србистике: од иманентних одлика Ковачевићеве научне мисије, преко утицаја, структурисања методолошких поступака и интерпретативних ставова, доминантних интертекстуалнх веза, до надградње филолошке традиције. Други део рада посвећен је посебним аспектима Ковачевићевих текстова и њиховим релацијама, оригиналним научним ставовима, у променама лингостилистичке перцепције и аргументованим одбранама стилских поступака значајних аутора српске књижевности. Ковачевићева анализа и синтеза стилских доминанти остварена је у циљу очувања и унапређивања историјских и савремених вредности српске књижевности, језика и културе.

Кључне речи: Милош Ковачевић, научни значај, интертекстуални аспекти, лингвостилистика, србистика, стилематичност, стилогеност.

*dusan.zivkovic@filum.kg.ac.rs

** Рад је део истраживања на пројекту 178018 Друштвене кризе и савремена српска књижевност и култура: национални, регионални, европски и глобални оквир Министарства просвете, науке и технолошког развоја Републике Србије. 


\section{УВОД}

У циљу очувања и развоја филологије у Србији, као и побољшања њене позиције у европским и светским научним круговима, неопходно је проучавање научних доприноса филолога који су непосредно утицали на обликовање српске филологије, пренели, надргадили светске филолошке токове и створили оригиналне теорије и ставове.

У овом контексту, издвајамо научну мисију Милоша Ковачевића (1953), редовног професора за Савремени српски језик, Стилистику, Семантику и Општу лингвистику, на универзитетима у Београду, Крагујевцу, Бохуму, Сарајеву, Источном Сарајеву, Никшићу, Нишу, Петрињи, Косовској Митровици и Бањалуци. Милош Ковачевић је аутор преко 400 научних и стручних радова, као изначајних научних монографија и уџбеника ${ }^{1}$, из лингвистичких области које се међусобно прожимају и допуњују у мисији очувања и надградње српског језика.

У докторској дисертацији: Систем синтаксичких јединица за обиљежавање узрока у савременом српскохрватском књижевном језику (1984) Ковачевић је створио основе за будућу научну мисију трагања за узроцима, процесима и исходима структурисања српског језика у синхронијској и дијахронијској перспективи, да би остварио синтезу општих семантичких перспектива у књизи Узрочно семантичко поље (Сарајево: Свјетлост, 1988) и наставио синтаксичка проучавања у утицајним књигама: Кроз синтагме $u$ реченице (Свјетлост, Сарајево, 1992), Синтакса сложене реченице у српском језику (Београд: Рашка школа; Србиње: Српско просвјетно и културно друштво Просвјета, 1998; Београд: Јанус), Суштаствено и мимогредно у лингвистици, Подгорица: Универзитет Црне Горе 1996), Синтаксичка негащија у српскоме језику (Ниш:Универзитет у Нишу, 2002), Граматичка питања српскога језика (Београд: Јасен, 2011; Београд: Донат граф) и О реченици и ғеним члановима (Београд: Јасен; Београд: Дијамант принт, 2015).

Логична надградња Ковачевићеве научне делатности остварена је у књизи: У одбрану језика српскога - и даље (прво издање - Београд: Требник, 1997; друго, допуњено издање - Београд: Требник, 1999), док је полицентричност, као и порекло српског језика образложио у књизи Српски језик и српски језищи (Београд: БИГЗ, СКЗ, 2003). Наравно, у овој научној полемици, било је неопходно одбранити се од ненаучних политичких тврдњи, у књигама: Против неистина о српскоме језику (Источно Сарајево: СКПД Просвјета, 2005) и Српски језик у вртлогу политике (у суауторству с Михаилом Шћепановићем, Подгорица: Матица српска - Друштво чланова у Црној Гори, Подгорица: Лутрекс, 2011), да би у Србистичким темама (Крагујевац: ФИЛУМ, Београд:

\footnotetext{
${ }^{1}$ Милош Ковачевић је и аутор 16 уџбеника српскога језика за основну и средњу школу.
} 
Кум 2007) Ковачевић остварио синтезу општих аспеката очувања и развоја србистике.

Ковачевићев научни допринос евидентан је и у стилистици - у теоријским ставовима о природи и функцијима стилских фигура у књигама Стилске фигуре и књижевни текст (Београд: Требник, 1998) и Стилистици и граматици стилских фигура (прво издање: Граматика и стилистика стилских фигура, Сарајево: Књижевна заједница Другари, 1991; друго, допуњено издање: Стилистика и граматика стилских фигура Подгорица: Унирекс 1995; треће, прерађено и најпотпуније издање: Крагујевац: Кантакузин, 2000), као и у примени теоријских ставова на значајна дела српске књижевности, док је синтеза лингвостилистичких тема обликована у књигама: Граматичке $u$ стилистичке теме (Бања Лука: Књижевна задруга, 2003), Списи о стилу и језику (Бања Лука: Књижевна задруга, 2006), Стилска значења и зрачења (Ниш: Филозофски факултет, 2011) и Лингвостилистика књижевног текста, (Београд: СКЗ, 2012).

Након овог краћег уводног прегледа најзначајних домена Ковачевићеве научне делатности, треба истаћи да смо у овом раду изабрали за анализу Ковачевићеву Лингвостилистику књижевног текста јер сматрамо да окупља све доминантне аспекте за описивање и образложење његовенаучне мисије: „Описујући и систематизујући ово деликатно поље разумевања и једну историју мишљења као историју културе, Ковачевић истовремено отвара деликатну причу о тумачењу идентичности и неидентичности знакова" (Бошковић 2013: 80). Лингвостилистика књижевног текста, као „монолитна књижевно-научна симфонија" (Стојановић 2012: 26) представља оригиналну примену Ковачевићевих основних теоријских и интерпретативних ставова.

Лингвостилистика књижевног текста, као „немерљив допринос лингвостилистичким истраживањима на примерима из српске књижевности" (Стојановић 2012: 14) састоји се из 14 радова са научних скупова (уп. Ковачевић 2012: 375), писаних од 2009. до 2011. године. Радови су различите тематике: од проучавања српске књижевности с краја 19. века до савремене поезије, али истовремено, евидентно је да књига представља кохерентну целину; суштину метатекстуалних аспеката одређује Ковачевић у „Напоменама о књизи”: „Та анализа је искључиво стилистичка, и то лингвостилистичка, при чему се овдје под лингвостилистиком подразумијева јединство лингвистичке и књижевне стилистике структуралног или боље речено: структурално-семиотичког типа" (Ковачевић 2012: 375).

Предмет овог рада представља анализу научног значаја и доминантних интертекстуалних аспеката Лингвостисилистике књижевног текста Милоша Ковачевића, посредством аналитичко-синтетичке методе: од општих карактеристика Ковачевићеве научне мисије, структурисања односа делова 
и целине, методолошких поступака и интерпретативних ставова, утицаја, дијалога, доминантних интертекстуалнх веза у контексту светске филогије, као и у контексту балканских, србистичких и/или сербокроатистичких домена, до структурирања оригиналних интерпретативних ставова у Ковачевићевим текстовима.

\section{1. ОПШТИ АСПЕКТИ ЛИНГВОСТИЛИСТИКЕ КЬИЖЕВНОГ ТЕКСТА У КОНТЕКСТУ ОДНОСА СВЕТСКИХ ФИЛОЛОШКИХ ТОКОВА И СРБИСТИКЕ}

\section{1. Интердисциплинарност Лингвостилистике књижевног текста}

Ковачевићева научна мисао подразумева интердисциплинарност као део тоталитета проучавања језика и књижевности, у свести о међусобном преплитању и неопходности бављења језичком структуром и уметничком вредношћу у анализи књижевног текста (уп. Јакобсон 1966; Кајзер 1973), „на свим нивоима лингвистичке анализе, од фонолошког до текстуалног” (Ковачевић 2012: 119). На тај начин, Ковачевић тежи свеобухватности „интегрисане (лингво)стилистике, што ће рећи стилистике језичког израза као лингвистичке стилистике у ужем смислу, и стилистике умјетничке вриједности језичког израза као линвостилистике” (Ковачевић 2012: 87).

Такође, у циљу поучавања природе интердисциплинарности, одабрали смо у овом делу рада доминантне интертекстуалне аспекте Лингвостилистике къижевног текста (уп. Бахтин 1995²; Кристева 1967; Барт 198633) да бисмо

${ }^{2}$ Наиме, Бахтин је сматрао да се све лексеме у језичком систему налазе у условљеном и интерферирајућем односу. Тако се ствара дијалогизам који је својствен сваком тексту у оквиру социјалног контекста.У идеји повезаности текстова, Бахтин поима текст као „исказ”, систем значења који се налази у „дијалошкој узајамности” и „одражава све текстове (у границама) дате мисаоне сфере" (цит. према: Ерор 2002: 236)). Под утицајем Бахтиновог учења о дијалошкој узајамности текста и полифонији, Јулија Кристева је у студијама Bakhtine. Le mot, le dialogue et le roman и Pourune semiologie des paragrammes, дефинисала термин „интертекстуалност” („,l'intertextualite”). Међутим, за разлику од Бахтинове идеје контекста у „размени смисла” (цит. према: Ерор 2002: 238), Кристева истиче стварање значења, анализирајући ипак више интенције аутора од активне улоге читаоца: „Књижевни текст се умеће у целину текстова: он је писање - pеплика (ecriture - replique) (функција или негација) неког другог (неких других) текстова. Својим начином писања, читајући пређашњи или истовремени књижевни корпус, аутор живи у историји, и друштво се уписује у текст" (цит. према: Ерор 2002: 238). Другим речима, не може постојати текст који би сам по себи чинио аутономну категорију, већ мора бити тумачен у зависности од културног коิда и времена коме припада, а шире посматрано - и његовог дијалога са традицијом. Јулија Кристева тако обједињује спољашњи и унутрашњи приступ у проучавању књижевности, посматрајући текстове као системе знакова културе (уп. Живковић 2016: 9).

${ }^{3}$ Ролан Барт (Roland Gérard Barthes,1915-1980) одредио је интертекст са становишта епистемологије и филозофије језика: „Појам интертекста доноси теорији о тексту социјални 
објаснили Ковачевићеву интетртекстуалну свест о надоградњи традиције, могућности примена његових теорија на различите филолошке дисциплине, као и иновативност тоталитета његове научне мисије. Лингвостилистика и књижевна стилистика у Лингвостилистици къижевног текста налазе се, пре свега, у коресподенцији са морфологијом, синтаксом, семиотиком, семантиком, наратологијом и версификацијом, у споју синхронијске и дијахронијске перспективе.

\section{2. Ковачевић и формализам}

\subsection{1. Општи аспекти}

Московска и петроградска школа руског фомализма обликовале су Ковачевићеву свест о међузависности бављења језичком структуром и литерарношћу књижевног текста. Истичемо следеће аспекте који се издвајају по значају многобројних креативних утицаја руског формализма: метод, општа полазишта, поимање форме, литерарност, принципе грађења текста, семантичку аутономију текста, онеобичавање у односима лингвистике, поетике и стилистике (уп. Јакобсон 1973, Виноградов 1971), („начела структурисања”) (Ковачевић 2012: 128), доминанте, амбигвитет, аутореференцијалност, начела еквивалентности, поетску, метајезичку и конативну функцију језика.

На пример, Ковачевић започиње анализу „Графостилематичности Ногове поезије" постављајући у први план основни метод и предмет формализма: „Графостилематски онеобичајен сваки елемент у први план ставља форму као „главног јунака”: „семантику исијава сама форма у чијој је дубокој поетској сјени „удјенути” смисаони садржај” (Ковачевић 2012: 78). Такође, у раду „Пролептичка фигуративност у Ракитићевој поезији”, Ковачевић истиче општи став који означава његов начин поимања природе, функције и вредности поезије: „Јер без савршенства форми нема језички утемељеног поетског значења, а без амбигвалног значења нема ни велике поезије” (Ковачевић 2012: 116).

Поред овог основног утицаја, евидентно је да Ковачевић и унапређује формалистичке теорије, спајајући синхронијску и дијахронијску перспективу. На тај начин, формалистичка мисао наставља да се модификује у плурализму савременог доба, као један од чинилаца очувања научне мисли, умножавајући своје облике и значења. Дакле, Ковачевић користи домете руског формализма,

аспекат: цио језик, ранији или сувремени, долази до текста, не слиједећи пут насљедства или свјесног опонашања, него дисеминације - фигура која јамчи да текст нема статус репродукције, него продукције (тачније: производности)" (цит. према: Ерор 2002: 236). Барт, дакле, посматра друштвене домене интертекстуалности, као и Јулија Кристева, у ширем, културолошком смислу. Међутим, он прецизира и естетску позицију оригиналности стварања. Дакле, чак и преузети текст, транспонован у другом склопу, постаје нова креација. 
али и реактуелизује и надограђује њихова полазишта у савремениим лингвостилистичким перспективама 21. века, стварајући оригинални теоријски и интерпретативни систем.

\subsection{2. Утицај, примена и надградња појмова онеобичајења и} „отежане форме” Виктора Шкловског

У раду „Крњевићева ’Пјесан о жалној судби’ у лингвостилистичком кључу”, Ковачевић цитира Шкловског (Ви́ктор Бори́сович Шкло́вский, 1893-1984), у домену „отежане форме” (Шкловски 1991: 449) која „захтијева продужену перцепцију, и тиме реципијенту скреће пажњу на свој готово уникатан статус, а самим тим и на структуру цијеле пјесме" (Ковачевић 2012: 127).

Такође, Ковачевић тежи и објашњењу система онеобичајења (уп. Ковачевић 2000: 321) у анализи односа устаљених и нових књижевних поступака, анализирајући узроке, процесе њиховог структурирања, као и њихове исходе у књижевном делу. Ковачевић примењује, прецизира и универзализује кључни поступак онеобичајења (рус. остране́ние, срп. онеобичајење, онеобичавање, очуђење). Тако заправо проширује појам онеобичајења, овога пута, посматрајући теоријске поставке Шкловског и у ширем смислу, стварајући систем значења у коме сада у центру пажње није само онеобичајење као поступак који код читаоца ствара изненађеност, новину, већ онеобичајење у Ковачевићевој перспективи постаје и откривање новог начина посматрања света посредством кога се перципира књижевно дело. Дакле, Ковачевић примењује појам онеобичајења не само на грађење књижевног дела, него и на онтолошки принцип спознаје семантичког тоталитета.

\subsection{3.Утицај, примена и надградња Јакобсонових теорија}

У Ковачевићевим теоријским ставовима евидентан је утицај целокупне теоријске мисли Романа Јакобсона (Роман Осипович Якобсон, 1896-1982) од формалистичког до структуралистичког периода, у анализи различитих књижевних праваца: од проучавања дела Лазе Костића до поезије 21. века.

Пре свега, Ковачевић преузима дефиницију доминанте од Јакобсона, као основу појмовног система, актуелизујући Јакобсонов формалистички принцип поимања доминантних елемената у књижевном делу, а у најширем смислу - и доминанте у мисаоном систему, примењујући и надграђујући сам начин размишљања, начин перцепције и уопште - Јакобсонов начин поимања језика и књижевности.

Након појма доминанте којим је дефинисан однос према анализи књижевног дела уопште, од селекције кључних аспеката, у раду „Пролептичка фигуративност у Ракитићевој поезији" Ковачевић истиче амбигвитет (амбигуитет) 
као кључни аспекат умножавања значења ,јер амбигуитет представља неотуђиву унутрашњу одлику сваке поруке усредсређене на саму себе, - укратко пратећу карактеристику поезије” (Јакобсон 1966: 313; цит. према: Ковачевић 2012: 105). Дакле, текст сугерише да читалац не треба да буде искључив и линеаран у интерпретацији, већ различита значења могу истовремено деловати у књижевном делу. Тако се, посредством амбигвитета, који се рачвају у нове комбинације, ствара многострукост значења дела.

Ковачевић примењује Јакобсонов принцип еквивалентности као основ формалне и семантичке структуре, као и генерално - у поимању односа делова и целине (уп. Ковачевић 2012: 121). На пример, у раду „Крњевићева Пјесан о жалној судби' у лингвостилистичком кључу” Ковачевић истиче да је „тај принцип еквивалености најчешће препознатљив, а неријетко и сводљив на принцип паралелизма" (Јакобсон 1966: 296; цит. према: Ковачевић 2012: 119) a „поетска функција пројектује принцип еквивалентности из осе селекције у осу комбинације” (Јакобсон 1966: 310; цит. према: Ковачевић 2012: 119). Такође, Ковачевић цитира Јакобсона у односима поетске и конативне функције језика: „Поетска функција језика тако је надограђена конативном функцијом, функцијом која у средиште ставља примаоца" (Ковачевић 2012: 126).

Дакле, Ковачевић анализира динамичност контекста књижевног дела, као и динамичност рецепције и исходе Јакобсонових теорија, тежећи да објасни и процесе стварања, као и дифузности амбигвитета, њихове односе, природу и функцију сваке етапе динамизације контекста, као и особину поетске функције језика посредством начела еквивалетности и паралелизма.

\section{3. Бахтинов утицај}

У теоријској мисли Милоша Ковачевића видљив је утицај Михаила Бахтина (Михаи́л Миха́йлович Бахти́н, 1895-1975), великог руског филозофа, семиотичара и теоретичара књижевности, „сапутника руских формалиста” (Милосављевић 1985: 374), али и филолога који је превазишао формалистичке границе и поставио основу савременог проучавања језика и књижевности. Овај утицај огледа се, пре свега, у Ковачевићевим стилистичким проучавањима повезаних са синтаксом и наратологијом, посебно у односима полифоније, дијалогизма, управног и неуправног говора: „Дијалошка је метода омогућила Бахтину да превлада границе семантичке аутономије текста којој су у почетку били склони руски формалисти” (Милосављевић 1985: 378). На овај начин је Ковачевић преко Бахтиновог утицаја превладао формалистичке границе иако је задржао основне формалистичке домете у проучавању форме.

Експлицитни примери примене Бахтинове теоријске основе остварени су у радовима: „Синтаксичко-стилистичке особине слободног неуправног 
говора у романима Меше Селимовића и Скендера Куленовића” и „О типовима туђег говора у роману Сара Петра Сарића” које повезује општи став: „Ако - слиједећи Бахтина - прихватимо да је „туђи говор у говору, исказ у исказу, али истовремено и говор о говору, исказ о исказу” (Бахтин 1980: 128; цит. према: Ковачевић 2012: 311), јер је у слободно-неуправном говору „с апстрактно-граматичке тачке гледишта - говори аутор, док с тачке гледишта стварног смисла - говори јунак" (Бахтин 1980: 164) [...] Он је увијек, за разлику од директног и индиректног говора, доживљени говор" (Ковачевић 2012: 322).

Такође, Бахтин је плодотворно утицао на Ковачевића у стварању интерпретативне свести о равноправности различитих семантичких аспеката у делу. Управо у овом домену драгоцен је Бахтинов појам полифоније, који је постао не само један од најпримењивијих у интерпретацији књижевног дела, већ је поимање полифоније утицало на афирмицију плурализма идеја (за разлику од искључивости спољашњих или унутрашњних приступа) од шездесетих година 20. века до савремене књижевно-теоријске мисли и уметничке праксе 21. века. Дакле, Бахтинови ставови, као мост од формализма ка семиотиоци, постају општи чиниоци Ковачевићевог односа према дијалогу, управном, неуправном говору, као и поимању природе и функција књижевности.

\section{4. Стилематичност и стилогеност}

У анализи „Туђег говора у роману Сара Петра Сарића” Ковачевић користи стилистички метод Леа Шпицера (Leo Spitzer, 1887-1960), утицајног романисте и хиспанисте, једног од утемељивача стилистичке критике: „И који упоришну интерпретативну тачку проналази у карактеристичној језичкој особини...” (Ковачевић 2012: 310). Шпицерово откривање духовног етимона заправо је блиско и Јакобсоновом поимању доминанте, а (посредно или непосредно) присутно (у интерференцији са наведеним теоријама) у готово свим Ковачевићевим радовима из Лингвостилистике књижевног текста. Наведени појмови представљају Ковачевићеве оријентире у проучавању језика и књижевности уопште, а у ужем смислу - у селекцији и дефинисању кључних аспеката стилемантичности и стилогености у књижевном делу: „Стилематичност је, дакле, структурно ткање језичких јединица. Будући да свако ткање мора бити сврховито, стилогеност је ефекат тог ткања, уметничке вриједности, језичке јединице као формалне структуре" (Ковачевић 2012: 61). У овом аспекту, Ковачевић примењује и прецизира Прањићеву дистинкцију: „стилогеност је оцјена фунцкионалности стилема. Дакле, није сваки стилем стилоген” (Прањић 1968: 71; цит. према: Ковачевић 2000: 323).

Поред ове неопходне дисктинкције, треба истаћи да у Лингвостилистици књижевног текста Ковачевић анализира управо примере из српске књижевности код којих постоји узајамност стилематичности и стилогености. 
На пример, у раду „Крњевићева 'Пјесан о жалној судби’ у лингвостилистичком кључу”, Ковачевић истиче аспекте „код којих је поетска функција резултат хармоније стилематичног и стилогеног плана свих њених конститутивних и 'интегрисаних' јединица" (Ковачевић 2012: 130).

Такође, Ковачевић упућује и на богату аристотеловску традицију проучавања стила, (као и на латинско порекло речи текст (textum) - ткање, уп. Ковачевић 2000: 319-325) у односима међузависности делова и целине, истовремено обједињујући цивилизацијску синтезу ${ }^{4}$ проучавања феномена стила и савремену лингвостилистичку анализу текста.

Овакво разумевање структуре ${ }^{5}$ од својих античких основа до савремених перспектива, евидентно је упроучавању понављања која одражавају „дјелимичну еквивалентност" (Ковачевић 2012: 226) у Рефузу мртваку Видосава Стевановића, у коме Ковачевић цитира Лотмана (Ю'оий Миха́йлович Ло́тман; 1922-1993), ,jер јој то не дозвољава да се аутоматизује и постане структурно редундантном" (Лотман 1976: 189; цит. према: Ковачевић 2012: 226), узимајући, такође, за класификациону основу и интонационе моделе Карцевског. На тај начин, Ковачевић осавремењује и унапређује ове теоријске системе посредством којих анализира доминанте Стенавовићеве прозе.

Поступак комбиновања различитих теоријских система, а у ширем смислу - и различитих дисциплина, у циљу унапређивања анализе доминантних аспеката у књижевном делу, карактеристичан је и у раду „Крњевићева 'Пјесан о жалној судби' у лингвостилистичком кључу” у коме Ковачевић цитира Речник симбола Шевалијеа и Гербрана (уп. Ковачевић 2012: 122), на пример, у симболици воде, како би приказао однос митолошких аспеката и употреба анадиплозе као моста „за семантичку везу поља, ливада и извора” (Ковачевић 2012: 122). Вишеслојност проучања представља додатну вредност ове лингвостилистичке анализе у којој Ковачевић користи и архетипску критику у проучавању односа стилогености и стилематичности.

${ }^{4}$ Поред аристотеловске традиције, Ковачевић спаја античку и савремену мисао и у односу према Платоновом поимању језика: „Стилистика онимских назива у роману Jonem суданија Тихомира Левајца” (Ковачевић 2012: 304): „А тај посупак познат још од Платона и његовог Кратила (Платон 2000); јесте поступак што га Женет зове епонимија имена" (Женет 1985: 22; цит. према: Ковачевић 2012: 304).

${ }^{5}$ Односе структуре и њених модификација у стварању нових књижевних форми, илуструје и Ковачевићево цитирање студије „Структура, функиија, знак, вредност Јана Мукаржовског (Београд: Нолит, 1987) у раду „Пролептичка фигуративност у Ракитићевој поезији”: „Такву форму поруке доживљавамо као насиље над материјалом, насиље извршено са сврхом да у материјалу побуди естетско дејство” (Мукаржовски 1987: 231; цит. према: Ковачевић 2012: 115). 


\section{5. Версификација и поетска структура}

У раду „Графостилематичност Ногове поезије” Ковачевић цитира „Границе сонета" Клајва Скота (Clive Scott) да би показао не само широку примењивост ове теорије, него и свест да Ногов поетски опус припада и српској и светској књижевности, обликујући „идентитет” сонета (Скот 1978: 325; цит. према: Ковачевић 2012: 68) у савременој поезији.

Такође, у проучавању Ногове поезије, Ковачевић цитира став Марије Ренате Мајенове о песничкој конструкцији текста: „Песник конструише текст - а то је несумњиво прагматичка вредност - да би прималац био принуђен да испроба неколико начина његових интерпретација" (Мајенова 2009: 423; цит. према: Ковачевић 2012: 78). Другим речима, за уско специјализована версификацијска проучавања неопходно је прво успоставити базу у проучавању структуре текста, као односа форме и семантике дела.

Ова интенција је очигледна и у раду „О језику и стилу Петра Пајића”, који је одређен типичним Ковачевићевим поступком анализе односа версификације и лингвостилистике: „И још је једна заједничка карактеристика свих римованих изострофичних Пајићевих пјесама, а то је графостилематика интонационог записа" (Ковачевић 2012: 201).

Дакле, све наведене версификацијске одлике Ковачевић посматра у домену односа стилематичности и стилогености, анализирајући све слојеве поезије, од општих до посебних аспеката, спајајући лингвостилистику, теорију књижевних жанрова и версификацију.

\section{6. Стилистички аспекти у контексту србистике и/или сербокроатистике ${ }^{6}$}

У Лингвостилистищи књижевног текста кључна је мисија одбране и очувања српског језика, књижевног и културног идентитета ${ }^{7}$, као и у тежњи ка очувању и унапређивању филологије у Србији уопште. У овој вишедеценијској делатности, Ковачевић има свест о два аспекта: а) да би се очувао идентитет српског језика и књижевности, неопходно је унапредити све филолошке дисциплине и посматрати их као део тоталитета, да би у сваком нивоу српски језик и књижевност могли бити одбрањени и унапређени; б) неопходно је детаљно познавање различитих ставова у оквиру србистике и/или сербокроатистике, њихова синтеза, као и комуникација мишљења, са посебним фокусом на лингвостиличке домене као примарне области ове књиге. У овом контексту, истичемо два рада који представљају осврт на претходнике у лингвостили-

\footnotetext{
${ }^{6}$ У конципирању овог поднаслова поштовали смо Ковачевићеву дихотомију.

${ }^{7}$ Овај аспекат ћемо детаљно анализирати у поглављу „2.4. Проучавања деоба језика, народа и тежња ка одбрани српског идентитета".
} 
стичким проучавањима: „Анализе Шантићеве пјесме Вече на шкољу и развојни путеви лингвостилистике код Срба” и „О поетизмима Лазе Костића”.

Да бисмо увидели иманентне карактеристике наведених односа, неопходно је започети анализу Ковачевићевим односом према стилистичкој традицији. На пример, у предговору књиге, под насловом „Књижевно-научна симфонија”, Бранко Стојановић отвара перспективе проучавања Ковачевићевог односа према Богдану Поповићу: „За разлику од оних тумача књижевно-језичког дела чијим анализама (,анализама”!) не претходи пажљиво, вишестепено читање, Ковачевићеве лингвостилистичке анализе највећма подсећају на реафирмацију „теорије ред-по-ред” Богдана Поповића” (Стојановић 2012: 10). У духу надргадње ове значајне опсервације, додаћемо да је Богдан Поповић започео унутрашњи приступ проучавању књижевости паралелно, па чак и пре водећих блиских, светских токова детаљних проучавања текста-,ред-по-ред” (као што је англоамеричка нова критика са методом close reading - „пажљивог, детаљног читања"). Такође, Богдан Поповић се (у складу са својом мисијом књижевног критичара и професора српске и компаративне књижевности) посветио претежно књижевној стилистици и књижевној критици у ужем смислу и тако постао путоказ књижевног укуса. С друге стране, имајући плодотворни утицај Поповићеве мисије, Ковачевић је надоградио, проширио и осавременио Поповићеве ставове, укључивши и лингвостилистику и књижевну стилистику, као и савремене термине, методе и сазнања од руског формализма до 21. века. Другим речима, ако ову паралелу објаснимо односом стилематичности и стилогености, Поповић је, уз основне дескрипције стилематичности, више пажње посветио стилогености, којој је дао драгоцени допринос и омогућио да за неколико генерација у српској филологији настану научне мисије попут Ковачевићеве, а Ковачевић је тежио да подједнако обухвати и стилематичност и стилогеност, укључивши и више лингвистичких дисциплина.

Такође, поред овог плодотворног утицаја, треба споменути и значајне разлике. Наравно, Ковачевићу је блиска теорија Богдана Поповића „ред по ред" у методолошком смислу, али не и Поповићева осуда значајних сегмената поезије Лазе Костића (уп. Ковачевић 2012: 38). Наиме, Ковачевић заправо превреднује и Поповићев допринос имплицирајући управо теорију „ред по ред" као његово основно достигнуће које може да буде плодотворно и у савременим проучавањима поезије, али Ковачевић не заступа Поповићеве критичке ставове у овом домену, већ истиче стилематичност и стилогеност у одбрани поезије Лазе Костића.

У односу према историји стилистике, карактеристично је и Ковачевићево проширивање Маретићевог поимања граматичке правилности стилског израза (уп. Ковачевић 2012: 37), као и дијалог са Белићевом опсервацијом о генијалности уметника, који од постојећих средстава стварају нову уметност 
(уп. Ковачевић 2012: 38). Наравно, пошто неологизми Лазе Костића не спадају у стандардне језичке јединице, Ковачевић имплицира да Маретићеви и Белићеви ставови имају своју примену, али да је неопходно проширити и осавременити њихове домене, како би се проучавале Костићеве иновације у поетском језику.

Поред односа према историји стилистичких проучавања, треба посветити пажњу и односу према новијим лигвостилистичким аспектима. На пример, Ковачевић истиче значај Теорије књижевности Драгише Живковића и фоностилистичке анализе песме Вече на шкољу (у првом издаљу из 1955) и Живковићев текст: „Вече на шкољу Алексе Шантића - стилска анализа”, као „тоталну лингвостилистичку анализу” (Ковачевић 2012: 9). Такође, Ковачевић запажа Тартаљин став о стилу као „пркошењу обичном говору” (Тартаља 1998: 111-112; цит. према: Ковачевић 2012: 21), дометима оригиналности Шантићевог стилског израза, као и принципа фигуративности (уп. Ковачевић 2012: 31).

Са ранијих генерација филолога прелазимо на Ковачевићев однос према савременицима: у интерпретативним ставовима песме Вече на шкољу, карактеристично је и Ковачевићево истицање значаја Опште стилистике и Стилистике српскога језика Радоја Симића, као потврде за „метасемију и метаплазму у творачком процесу" (цит. према: Ковачевић 2012: 21). Шире посматрано, на тај начин Ковачевић истиче и значај научне делатности Радоја Симића у српској стилистици.

Такође, Ковачевић запажа Грдинићев став о Вечери на шкољу као „криптоформној песми" (уп. Ковачевић 2012: 29-31), што је свакако и подстрек за детаљнију анализу односа версификације и стилистике. Грдинићеви ставови из версификације представљају теоријску основу и у Ковачевићевој анализи „Стилско-језичких особина Језикрвља Зорана Костића” у домену дефиниције азбучног акростиха и „његове магијске и мнемотехничке функције у усменом преношењу” (из: Ковачевић 2012: 141),

Након ових теоријских аспеката, треба истаћи да на Ковачевића утичу књижевно-историјске перспективе Владете Јанковића, који Аницу Савић Ребац, Вељка Петровића, Станислава Винавера и Исидору Секулић посматра

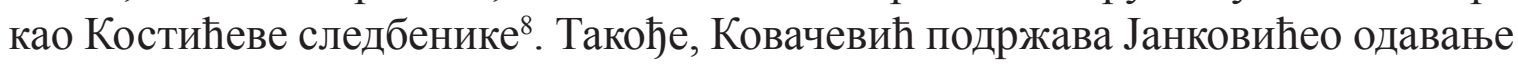
почасти Костићеве поезије, а посебно његових неологизама, (уп. Ковачевић 2012: 57), као један од подстрека за писање рада „О поетизмима Лазе Костића”, у коме је Ковачевић својим оригиналним научним доприносом, продубио и образложио ставове о стилској вредности Костићевих поетизама.

${ }^{8}$ У овом раду ћемо се задржати на општим аспектима научног значаја Ковачевићеве књиге, док би детаљана анализа Ковачевићевог односа према Костићевим следбеницима представљала предмет посебног рада. 
Након србистичких тема и односа теорије и историје књижевности у лингвоститичким србистичким темама, значајан аспекат Лингвостилистике кюижевног текста састоји се и у Ковачевићевим интертекстуалним дијалозима са хрватским теоретичарима књижевности и сербокроатистима. Поред основе стилематичности и стилогености у теоријама Крунослава Прањића (в. 1.4. Стилематичност и стилогеност), значајно је Ковачевићево истицање Шкребове улоге у развијању свести о књижевности као уметности речи у Југославији после Другог светског рата ${ }^{9}$, а такође и проучавања међуодноса макротекстуалног и микротекстуалног плана (уп. Ковачевић 2012: 88), да би, подстакнут Шкребовим опсервацијама, у раду о Ракитићевој поезији, Ковачевић анализирао „пролептичке микротекстове” (Ковачевић 2012: 88) .

Поред односа према општим стилистичким теоријама, карактеристичан је Ковачевићев однос према хрватским филолозима у доменима синтаксе и наратологије, посебно у образлагању Катичићевог разликовања слободног неуправног говора ${ }^{10}$ од обичног неуправног говора (уп. Ковавевић 2012: 191), као једне од основних методолошких поставки у раду „О језику и стилу Петра Пајића".

Такође, у „Стилско-језичким карактеристикама бајки Долина јоргована Тиодора Росића” Ковачевић је пошао од Франгешове дистинкције да је „слободни неуправни говор ступањ психологије до којега народни израз није дошао" (Франгеш 1963: 262; цит. према: Ковачевић 2012: 267). Даље, Ковачевић развија, осавремењује, проширује и надограђује Франгешову дистинцију у анализи разлике између народне и ауторске бајке и на тај начин ствара прецизнији и применљивији теоријски и интерпретативни систем.

На основу наведених аспеката, закључујемо да је у Лингвостилистици къижевног тескта, као и у целокупном Коваечићевом научном раду, постоје различити утицаји, интерференције становишта, интертекстуални дијалози, али и плодотворне полемике са србистичком/сербокроатистичком филолошком традицијом, у циљу стварања иновативних теоријских и интерпретативних ставова.

${ }^{9}$ У овом домену проучавања књижевности као језичке уметности, Ковачевић запажа и улогу студије Језик и књижевно дјело, Зденка Лешића, који је, у анализи Шантићевог стиха: „пучина плава спава” „образложио темељни појам Гирооове и Гироовски надограђене Бајијев(ск)е стилистике - појам избора и појам стилистичке варијанте” (Ковачевић 2012: 19), и на тај начин је пренео и прилагодио сербокроатистици најзначајније светске лингвостилистичке теорије, посебно у аспекту „звуковне вредности језичког знака” (Ковачевић 2012: 24).

${ }^{10}$ „Овај тип говора за који се сматра да је карактеристика само романескне умјетничке прозе, а који је данас најпознатији под именом слободни неуправни говор (в. нпр. Бити 1997: 120-122; Бал 2000: 32-39), док је код Бахтина (1980: 161-182) и у руској лингвистичко-књижевно-стилистичкој традицији увијек наз(и)ван неправи директни (управни) говор" (Кожина 2006: 251-252; цит према: Ковачевић 2012: 269-270). 


\section{2. АНАЛИЗА ПОСЕБНИХ АСПЕКАТА}

\section{1. Основни принципи класификације}

Милош Ковачевић је поделио Лингвостилистику књижевног текста на два дела. Поштујући „тематски, дисциплинарни и методолошки критеријум” (Ковачевић 2012: 375), као и редослед радова у књизи (уп. Ковачевић 2012: 375), због прегледности нашег излагања, основну концепцију класификоваћемо на мање подгрупе, да бисмо се осврнули на блискости тематских и идејних елемената, те да бисмо кохерентније одредили Ковачевићеве научне поступке.

У прву подргрупу сврставамо радове: „Анализе Шантићеве пјесме Вече на шкољу и развојни путеви лингвостилистике код Срба” и „О поетизмима Лазе Костића”, у доменима проучавање основа српске поезије, историје лингостилистике у Србији, као и Ковачевићевих преиспитивања устаљених ставова књижевне критике.

Другу подгрупу чини анализа поетских поступака у текстовима „Графостилематичност Ногове поезије” и „Пролептичка фигуративност у Ракитићевој поезији".

Трећу подргрупу у нашој анализи научног значаја Ковачевићевих радова чиниће анализа Ковачевићевих текстова у одбрани српског идентитета и српског језика: „Крњевићева „Пјесан о жалној судби” у лингвостилистичком кључу”, „Стилско-језичке особине Језикрвља Зорана Костића” и „Поетска одбрана језика српскога (из пера Момира Војводића и Милице Бакрач)”.

Овом анализом била би завршена класификација првог дела Лингвостилистике књижевног текста, а други део ћемо започети издвајањем четврте подгрупе радова, који се баве проучавањем доминанти у стваралаштву савремених писаца: „О језику и стилу Петра Пајића”, „Стилске доминанте у збиркама приповиједака Видосава Стевановића” и „Стилско-језичке карактеристике бајки Долина јоргована Тиодора Росића”.

Пету подгрупу чине односи лингвостилистичке анализе, ратне тематике и критике друштва у радовима: „Језичка слика рата у роману Топ је био врео Владимира Кецмановића” и „Стилистика онимских назива у роману Jonem Суданија Тихомира Левајца".

Шесту подгрупу смо издвојили према проучавању природе управног и неуправног говора: „О типовима туђег говора у роману Сара Петра Сарића” и „Синтаксичко-стилистичке особине слободног неуправног говора у романима Меше Селимовића и Скендера Куленовића". 
Све наведене подгрупе анализираћемо у доменима посебних аспеката Ковачевићевих радова: полазних тачака, природе, процеса анализе, односа према другим текстовима, исходима, до Ковачевићевих закључака, као и значаја појединачних текстова у структури Лингвостилистике књижевног текста.

\section{2. Однос према традицији у анализи Костићевог и Шантићевог поетског језика}

У прву подгрупу анализираних текстова треба сврстати радове: „Анализа Шантићеве пјесме Вече на шкољу и развојни путеви лингвостилистике код Срба” и „О поетизмима Лазе Костића” у којима се посматра, пре свега, стилски поетски ефекат, у доменима проучавања историјских аспеката српске поезије.

Како аутор наводи у напоменама, „Анализа Шантићеве пјесме Вече на шкољу и развојни путеви лингвостилистике код Срба" је прегледни рад, односно синтеза досадашњих лингвостилистичких проучавања, са даљом надградњом и егзактнијом поставком Ковачевићевих претходника у проучавању Шантићевог стваралаштва. Са објективне критичке временске дистанце, рад представља значајан допринос дијахронијском пруступу стилистичке анализе песме Вече на шкољу, слике дифузних перспектива развоја лингвостилистике у Србији, а у ширем смислу - и историји књижевности у теоријским аспектима, методолошким поступцима и интерпретативним ставовима.

Значајан је Ковачевићев компаративни приступ проучавања природе и фунција сваке релевантне стилистичке интерпретације Шантићеве песме у србистици. С друге стране, у раду о Лази Костићу евидентна је Ковачевићева полемичка позиција и промена рецепције Костићевог стваралаштва, чиме се повећава стилистички и, наравно, књижевно-историјски значај Костићевог стваралаштва. Наиме, доминантна је Ковачевићева одбрана слободе Костићеве употребе неологизама и полемика са претходним лингвостилистичким интерпретацијама, јер у указивању да се баш у овом аспекту, који је кроз историју перцепције сматран мање успелим аспектом Костићевог стила, Ковачевић управо проналази стилематичност, стилогеност, односно онеобичајење, инвентивност израза, стилску вредност, па чак и закључује да су неологизми „највреднији дио Лазине поезије” (Ковачевић 2012: 59). Закључујемо да ови радови представају допринос проучавању српске поезије уопште, као и пример примене водећих лингвостилистичких принципа у обједињавању дијахронијске перспективе - синтезе и преиспитивања утицајних ставова о Костићевој и Шантићевој поезији, као и инвентивних примена савремених лингвостилистиких принципа. 


\section{3. Графостилематичност Ногове поезије и пролепса у Ракитићевој поезији}

У проучавању поезије Рајка Петрова Нога (1945) и Слободана Ракитића 1940-2013), Ковачевић је истакао њихову истрајност неговања стилематичности и стилогености поетског језика, у припадности генерацији која је обликовала савремену српску књижевност ${ }^{11}$.

У раду,„рафостилематичност Ногове поезије” присутни су доминантни лингвостилистички и књижевнотеоријски аспекти, од односа делова и целине, улоге сонета у тоталитету Ноговог стваралаштва, прстенасте композиције Ногових сонета, до анализа мајускулних и минускулних графостилема (уп. Ковачевић 2012: 80) чија је „употреба условљена, по правилу, или семантичким (тропичним) или интонационо-синтаксичким разлозима" (Ковачевић 2012: 85). На тај начин, Ковачевић истиче Ногов допринос српској поезији, како у и иновацијама стиха и генерално - жанра сонета, тако и у посебним аспектима - језичким експериментима у употреби текстуалних и унутартекстуалних графостилема (уп. Ковачевић 2012: 63).

Ковачевић запажа да се Ракитићево „умијеће у творби пролептичких конструкција огледа и у лексичко-синтаксичким иновацијама" (Ковачевић 2012: 95) и да је у сагласју са поетским контекстом, односно - наведене језичке одлике доприносе уметничком ефекту, у хармонији семантике и форме, као и у духу неговања и одбране српског језика и индетитета: „Хармонизација стилогености и стилематичности на најбољи начин оповргава мишљења о примарно артистичким циљевима Ракитићевог савршенства форми” (Ковачевић 2012: 116).

Дакле, за разлику од књижевних критичара (уп. Јуришевић 2009: 107; Магарашевић 1990: 12, према: Ковачевић 2012: 87) који сматрају да је Ракитићева артистичност језичког израза у првом плану у односу на идејни систем дела, Ковачевићеве лингвостилистичке анализе представљају одбрану Ракитићеве поезије, истичући њене структуралне иновације, семантичке принципе, као и шири културни значај у српској књижевности.

${ }^{11}$ „Ногова поезија пуна је разноврсних, врло успјелих, веома и стилематичних и стилогених тропа и фигура (метафора и метономија посебно)" (Ковачевић 2012: 63). Такође, у поезији Слободана Ракитића (1940-2013) песника, политичара, есејисте, Ковачевић посматра значај „семантичке еквиваленције” (Ковачевић 2012: 93), као и генерално - хармонију односа форме и семантике. 


\section{4. Проучавања деоба језика, народа и тежња ка одбрани српског идентитета}

„Крњевићева 'Пјесан о жалној судби' у лингвостилистичком кључу”, „Стилско-језичке особености Језикрвља Зорана Костића” и „Поетска одбрана језика српскога (из пера Момира Војводића и Милице Бакрач)" представљају Ковачевићеве карактеристичне текстове о одбранама српског језика и идентитета, којима је посветио значајан део своје научне и друштвене делатности уопште (уп. Ковачевић 1999). „Крњевићева 'Пјесан о жалној судби’ у лингвостилистичком кључу" означава научни допринос у промишљању о деобама и имплицирању драма у српском роду и језику, спајајући семантичка, лингвостилистичка и версификацијска проучавања.

У раду „Стилско-језичке одобености Језикрвља Зорана Костића” Ковачевић укључује морфолошка, морфостинтаксичка и синтаксичка проучавања, користећи лингвостилистичке системе, синтаксичке анализе и версификацију, као и у проучавања историје језичког идентитета, а кроз анализу стила поезије Зорана Костића, Ковачевић пише и о српским историјским драмама и трагичним поделама, што представља додатну вредност овог рада. Ковачевић проучава стварање неологизама од њихових подстицаја, узрока, процеса њиховог структурисања, њихове интерференције и функције, до даљих исхода у односу на тоталитет поезије Зорана Костића и у српској књижевности, као и у ширем контексту - у питању односа према српском идентитету.

Такође, у „Поетској одбрани језика српскога (из пера Момира Војводића и Милице Бакрач)" Ковачевић је осудио незаснованост новопризнатог, црногорског (уп. Ковачевић 2008) и истакао да је српски језик језичка матица Црне Горе (уп. Ковачевић 2003а), у борби против „рашчетворења језика српскога” (Ковачевић 2012: 160). Тако заједничким снагама устају песници и лингвисти у одбрану језика српскога (уп. Ковачевић 1999; 2003а). У интерпретацији Војводићеве песме „Палимпсест сонет” приказана је основна идеја Ковачевићог поимања односа поезије, језика и националног идентитета: „У језику се чита историја, памћење једног народа, зато је свака пјесма српскога језика и палимпсестна пјесма, а као пелимпсестна - и пјесма у његову одбрану" (Ковачевић 2012: 162).

У структуралној анализи песама Момира Војводића и Милице Бакрач драгоцен је Ковачевићев закључак „да је, према свим лингвистичким и социолингвистичким критеријумима, у питању један полицентричан језик" (Ковачевић 2012: 153). У анализи лингвостилистичких особина збирке Самодржа језика српскога Момира Војводића, Ковачевић спаја објективност научног језика са критичком, поетском надахнутошћу: „Као да пјесник поручује: оно што нас као Србе стално детерминише - и на почетку и на крају - јесте језик српски, постојан као црква Самодржа" (Ковачевић 2012: 159). Такође, у пое- 
зији Момира Војводића и Милице Бакрач Ковачевић анализира и историјске драме српскога језика као и савремена оспоравања (уп. Ковачевић 2011) и поделе (уп. Ковачевић 2005б).

Наравно, поред ових кључних сличности, Ковачевић запажа и специфичности њиховог поетског израза, имплицирајући да је у Војводићевој поезији полемички тон транспарентнији, док акростих у Азбучнику Милице Бакрач има природу, „лирско-рефлексивних записа, лирских прожетих српских историјско-палимпсестних тема" (Ковачевић 2012: 165).

На основу наведених ставова, закључујемо да у овој групи радова Ковачевић показује да поезија Вука Крњевића, Зорана Костића, Момира Војводића и Милице Бакрач заслужује много више пажње у српској књижевности, од стилске вредности, до њихове ангажоване друштвене улоге у циљу очувања српског идентитета. Тако је Ковачевић у овим радовима створио основу за ово недовољно проучено, а кључно поље за очување српског националног идентитета.

\section{5. Проучавање језика и стилских доминанти у Пајићевом, Стевановићевом и Росићевом стваралаштву}

Радови: „О језику и стилу Петра Пајића”, „Стилске доминантне у збиркама приповиједака Видосава Стевановића” и „Стилско-језичке карактеристике бајки Долина јоргована Тиодора Росића" представљају анализе богатства језика у стилским доминантама савремених српскихписаца ${ }^{12}$.

„О језику и стилу Петра Пајића” је спона можда измећу дела књиге о поезији и дела књиге посвећеном прози, јер обухвата анализу ,језичко-стилских карактеристика Пајићевих књижевноумјеничких текстова као репрезената књижевноумјетничког стила" (Ковачевић 2012: 174).

Такође, да би успоставио целину са каснијим радовима у књизи о природи управног и неуправног говора, Ковачевић анализира „начело двојности и начело својеврсне експликације” (Ковачевић 2012: 193), конструкције преношења туђег говора, као и конструкције са значењем парадокса (Ковачевић 2012: 193).

Након проучавања језичко-стилских особина Пајићеве прозе, значајна је анализа природе и законитости односа слободног и везаног стиха у Пајићевој поезији. Иначе је чест манир у српској филологији да се само констатује постојање слободног стиха и „кршења” правила, док Ковачевић прецизно описује:

${ }^{12}$ Ковачевић је одредио распоред наведених радова имајућу у виду и старост аутора - од настаријег, Петра Пајића (1935-2017), преко Видосава Стевановића (1942) до најмлађег међу њима - Тиодора Росића (1950). 
иманентне карактеристике, процесе конституисања, структуру, синтаксичке и семантичке законитости и испитује процесе по којима фунционишу сложени, вишеслојни принципи Пајићевог стиха.

У раду „Стилске доминанте у збиркама приповиједака Видосава Стевановића", Ковачевић образлаже и оправдава аутопоетичке ставове које је Стевановић истакао у тексту „После десет година”, прецизирајући њихове домене у следећим стилским доминантама: „1) понављању као синтаксостилистичком поступку у Рефузу мртваку, 2) употреби црте као графостилематичком поступку - у Периферијским змајевима, 3) у употреби интерогативне реченице као семанто- и синтаксостилистичком поступку - у Царском резу" (Ковачевић 2012: 214). Тако заправо Ковачевић оправдава природу и домете стилских доминанти Стевановићевих књижевних поступака.

Након стилских доминанти Стеновићевих приповедака, у раду „Стилско-језичке карактеристике бајки Долина јоргована Тиодора Росића" Ковачевић полази од општих аспеката - од основних одлика и типова бајки, да би у посебним аспектима прецизно одредио позицију и вредност Росићевих бајки ${ }^{13}$ (уп. Ковачевић 2012: 255). Основне теме овог текста везане су за употребу управног и неуправног говорау ауторским и народним бајкама, посебно у крњем перфекту, аористу, као и у проучавању глаголских прилога, да би истакао закључак, значајан не само за анализу бајки Тиодора Росића, него и за дефинисање односа народних и ауторских бајки уопште: ,језичко-стилске особине најбитнији су критеријум којим се ауторска бајка и приближава и одваја не само од народне бајке него и од других типова умјетничке прозе" (Ковачевић 2012: 272). Ковачевић је на иновативан начин анализирао стилску језичку природу Росићевих бајки, а у ширем смислу - дао је научни допринос лингвостилистици, наратологији, синтакси и фолклористици.

Дакле, у свим наведеним радовима, евидентно је Ковачевићево реактуелизовање Пајићевог, Стевановићевог, Росићевог стваралаштва, као и истицање њихових стилских иновација у контексту најзначајнијих домета српске књижевности.

\section{6. Односи стилских особености и ратне тематике у анализама романа Владимира Кецмановића и Тихомира Левајца}

Радови „Језичка слика рата у роману Ton је био врео Владимира Кецмановића”, и „Стилистика онимских назива у роману Jonem суданија Тихомира Левајца", повезани су посредством Ковачевићевог проучавања разноликости

${ }^{13}$ „Обје верзије слободног неуправног говора - и са уводним глаголом типа verba dicendi (а) и без уводног глагола (б) Росић има у својим бајкама из Долине јоргована" (Ковачевић 2012: 268). 
синтаксостилема, као и у проучавању односа стилских карактеристика и ратне тематике.

У „Језичкој слици рата у роману Ton је био врео Владимира Кецмановића", Ковачевић објашњава комплементарност између структуре реченице и њене семантике, истичући да је ,парцелација реченице била најпримеренији поступак одсликавања стања ствари" (Ковачевић 2012: 280), пошто је све у рату испарцелисано, рашчлањено и уништено. Такође, карактеристични су „начини преношења туђег говора”- из перспективе дечака, у полифонији романа (Ковачевић 2012: 281); „начини (етно)језичке диферецијације говорника" приказани су у доменима интерференције и сукоба, сличности и специфичности различитих етничких, а самим тим и етнојезичких поимања света (уп. Ковачевић 2012: 288), а експресивности ових односа доприносе „специфични графостилемски поступци” (Ковачевић 2012: 293). Дакле, Ковачевић оправдава Кецмановићеве стилске поступке, аргументовано брани роман Ton je био врео од негативних критика и доказује да сваки од наведених стилских поступака заправо има своју суштинску функцију приказивања ,језичке слике рата" (Ковачевић 2012: 274). Према томе, сваки Кецмановићев стилски поступак упућује и на идејни систем од колективне до индивидуалне ратне трауме, преко отуђења и драме идентитета деведесетих година, до сугерисања универзалних, општељудских трагедија и трагања за изгубљеним хуманошћу савременог човека. Тако Ковачевић показује вредност Кецмановићевог дела у у описивању слике рата, као и у његовим универзалним естетским и стилским дометима. Другим речима, Ковачевић започиње анализу структуре Кецмановићевог језика, да би рашчланио његове доминанте и довео у везу структуру и семантику романа. Тако Ковачевић заправо доказује стилематичност и стилогеност Кецмановићевог романа - да се језичком формом заправо сугеришу основне идејне перспективе романа.

У раду „Стилистика онимских назива у роману Јопет суданија Тихомира Левајца", издвајамо Ковачевићеву компарацију Кочићеве и Левајчеве Суданије у суђењу „необичним затвореницима, ухапшеним Причама” (Ковачевић 2012: 297), у сличностима и разликама, као у перспективама разумевања оба времена. Овакве анализе интертекстуалних веза значајне су због односа развојних линија књижевности, стила, језика ${ }^{14}$, поетике, природе жанрова, као и односа друштвених околности, у разумевању континуитета српске књижевности.

${ }^{14}$ Такође, Ковачевић закључује: „У свом иронијско-саркастичном роману оними имају врло значајну улогу. А велики број је врло стилематичан, тј. има језички онеобичајену структуру” (уп. Ковачевић 2012: 299). Ковачевић издваја у одређеним онимима три подтипа: антропониме, топониме и ергониме (уп. Ковачевић 2012: 299) 


\section{7. Односи управног и неуправног говора}

Радови „О типовима туђег говора у роману Сара Петра Сарића” ${ }^{15}$ и „Синтаксичко-стилистичке особине слободног неуправног говора у романима Меше Селимовића и Скендера Куленовића" представљају значајне доприносе лингвостилистици и наратологији. Такође, уз стилске одлике, Ковачевић коментарише и историјске, актуелне и универзалне друштвене околности у роману Capa: „Као да полисемичност диобе провијава кроз све елементе структуре овог Сарићевог романа" (Ковачевић 2012: 310).

Коваћевић на тај начин описује вишеслојност и интерференције деоба: од деобе (диобе) у језичкој структури, преко принципа деобе у семантичком систему романа Сара, до деобе у историјским и околностима које директно одређују садашњост и на крају - до деобе као универзалне, трагичне одреднице. Оваква динамичност промена туђег говора означава и брзе промене наративних, и генерално - идејних перспектива, стварајући полифонију и свеобухватност епског принципа у роману Сара: ауторски (као представљачки) (Ковачевић 2012: 312) и неуправни говор (аутором опосредовани туђи говор) (Ковачевић 2012: 313). Тиме је оправдао „граматички хибридну конструкцију неуправног говора" (Ковачевић 2012: 314).

Ковачевић посматра односе између теорије епике и теорије драме, као и у ширем смислу - односе између драмског и епског принципа, увиђајући њихове сличности, као и специфичности: „Тај монолог, дакле, не мора бити драмског, конфликтног типа, може бити, на примјер, евокативног" (Ковачевић 2012: 317), посматрајући „интерференцију ауторског и управног говора” (Ковачевић 2012: 319): „управни дијалошки говор; (и тако је у цијелом роману: управним говором пренесени туђи говор увијек је ијекавски, а ауторов нараторски говор искључиво екавски” (Ковачевић 2012: 315); „та два говора чине једну интерјунктурну цјелину, што значи да оформљују једну вишеструкосложену реченицу" (Ковачевић 2012: 319). Овај аспекат има и шири смисао од анализе туђег говора јер имплицира подједнако неговање ијекавског и екавског у српском језику.

Ковачевић истиче да се у роману Сара Петра Сарића „на граматичком и граматичко-стилистичком плану јасно диференцира шест типова говора: 1) ауторски говор 2) индиректни говор 3) директни дијалошки говор 4) директни

${ }^{15}$ Рад „О типовима туђег говора у роману Сара Петра Сарића” представља спону између наведених радова о ратној тематици и завршог рада „Синтаксичко-стилистичке особине слободног неуправног говора у романима Меше Селимовића и Скендера Куленовића - наратолошки, синтаксички приступ”. Због блискости савремене тематике анализираних књижевних дела, овај рад је ближи радовима о стваралаштву Кецмановића и Левајца, док би по структуралном критеријуму био ближи групи радова о Селимовићу и Куленовићу. 
монолошки говор 5) недословни директни говор 6) слободни неуправни говор" (Ковачевић 2012: 327).

Допринос овог рада састоји се у томе што је Ковачевић описао, аргументовао „синтаксо-стилистичке комбинације, правећи тако хибридне конструкције” (Ковачевић 2012: 328), описао и образложио у језичкој структури као и у вредности дела стилематичности и у погледу стилогености иновативност у интерференцији и хибридизацији - сваку етапу процеса стварања комбинација, даље њихове путање и исходе, као и кључне тачке интерференција у деловима као и Сарићеве иновативности у целовитости романа.

Након проучавања Росићевог стваралаштва, завршни рад у књизи има „за примарни циљ опис специфичности употребе овог синтаксичко-стилистичког поступка у романима Тврђава Меше Селимовића и Понорница Скендера Куленовића” (Ковачевић 2012: 332). На пример, „и Куленовић и Селимовић слободни неуправни говор у трећем лицу (тј. с претварањем првога у треће лице) користе за преношење (препричавање) говорних ситуација у којима наратор није био говорни учесник (па макар био и учесник говорне ситуације)" (Ковачевић 2012: 336). Ковачевић оцењује слободни-неуправни говор као најпогоднији: ,jер ни један ни други аутор у наведеним романима објективно не приповиједају догађаје, они готово никада у опису догађаја нису неутрални, са њиховим активностима и говорним ставовима" (Ковачевић 2012: 349).

С друге стране, постоји и значајна разлика: Селимовић, користи слободни неуправни говор као конституент и ауторског и управног говора, за преношење садржаја изреченог управног говора, док Куленовић користи слободни неуправни као прожимајући елемент ауторског (нараторовог) говора, би преносио садржаје и изреченог и неизреченог управног говоора (уп. Ковачевић 2012: 336-337).

Дакле, ова компарација је значајан допринос наратолошким и лингвостилистичким проучавањима српске књижевности, пошто на великом броју примера Ковачевић запажа сличности и разлике Селимовићевих и Куленовићевих поступака, од структуре до идејних перспектива романа.

\section{3. ЗАКЉУЧАК}

У анализи научног значаја и интертекстуалних аспеката Лингвостилистике књижевног текста, једне од најзначајнијих српских филолошких књига у 21. веку, истакли смо да је Ковачевић извршио синтезу филолошке традиције, надоградио доминантне филолошке теорије и створио иновативни лингвостилистички систем. 
У првом делу рада анализирали смо опште аспекте Лингвостилистике къижевног текста у контексту водећих светских филолошких токова, као и у контексту балканске филологије, србистике и/или сербокроатистике.

Ковачевић примењује и надграђује теорије руског формализма, као и ставове Михаила Бахтина, у поимању природе, метода и циља проучавања књижевности, актуелизујући их у интерференцији са савременим лингвостилистичким аспектима.

Такође, у односима стилематичности и стилогенсти, истакли смо да Ковачевић укључује различите дисциплине у оквиру науке о језику и науке о књижевности, имајући у виду њихову комплементарност у расветљавању сложених језичких феномена, од антике до савременог доба, у примени на лингвостилистичке анализе значајних дела српске књижевности.

Након проучавања интертекстуалних аспеката у контексту светске филологије, испитали смо природу и значај Ковачевићевих теоријских и интерпретативних ставова у оквиру србистике и/или сербокроатистике, са посебним освртом на лингвостилистичке домете у Србији, од блискости, али и специфичности у односу на теорију „ред по ред” Богдана Поповића, до савремених лингвостилистичких теорија.

Ковачевић посматра стилско-језичке елементе у динамичком контексту, што представља допринос анализи језичко-уметничког тоталитета дела, коме није довољно пажње посвећено у савременим филолошким дисциплинама. Тако Ковачевић проучава кључне лингвостиличке аспекте, као и све фазе амбигвитета: од процеса структурисања, односа међу семантичким аспектима, до њихових интерференција и дифузних исхода.

Поред лингвостилистичких аспеката у ужем смислу, у версификацији је значајан Ковачевићев допринос у савременим филолошким токовима, јер је показао да је за проучавање природе и фунције структуре стихова неопходно укључити и шире аспекте морфологије, синтаксе, лингвостилистике, као и генерално - односе између форме и семантике дела.

Други део рада био је посвећен анализи посебних интерпретативних поступака. У Лингвостилистиции књижевног текста, Ковачевић анализира дела српске књижевности, признавајући им и доказујући вредност у стилским доминантама и жанровским карактеристикама светске књижевности.

На основу наведених ставова, закључујемо да је научни допринос Милоша Ковачевића у Лингвостилици књижевног текста, остварен у следећим доменима: а) увођењем оригиналних интердисциплинарних приступа, у циљу развоја лингвостилистике у Србији, као и образложења вредности српске књижевности, остварена су прилагођавања, примене и унапређивања доминантних светских теорија; б) значај ове књиге састоји се и у променама 
лингвостилистичке перцепције, као и аргументованим одбранама стилских поступака значајних аутора српске књижевности; в) Ковачевићева анализа и синтеза стилских доминанти остварена је у циљу очувања и унапређивања историјских и савремених вредности српске књижевности, језика и културе.

Ковачевићева свеобухватна лингвостистилистичка анализа књижевног текста је драгоцена у времену у коме постоје заговорници релативизма у проучавању у књижевности, као и уситњавања, а често и ограничених домета и једностраности лингвистичких дисциплина. Поред ових научних доприноса као путоказа будућих филолошких токова у Србији, истичемо Ковачевићеву одбрану идентитета српског језика, у циљу очувања свести о јединствености и саборности порекла српског језика и српског идентитета уопште. Ковачевићева научна мисија представља одбрану научности и достојанства целокупне српске филологије.

\section{ЛИТЕРАТУРА}

Bart 1986: R. Bart, Teorija o tekstu, preveo Miroslav Beker, Beograd: Republika, br. 12, 9-10.

Kristeva 1967: J. Kristeva, Bakhtine. Le mot, le dialogue et le roman, Paris: Critique, 239, Paris, 438-465.

Бахтин 1980: Mihail Bahtin, Marksizam i filofozija jezika, Beograd: Nolit.

Бахтин 1989: Mihail Bahtin, O romanu, Beograd: Nolit.

Бошковић 2013: Д. Бошковић, „Књижевност је лице језика: о лингвостилистичкој херменеутици Милоша Ковачевића”, Узданица, Краљево, $\mathrm{X} / 1,79-82$.

Виноградов 1971: В. В. Виноградов, Стилистика и поетика, превод с руског Предраг Лазаревић, Татјана Шеремет и Милован Милинковић, Сарајево: Завод за издавање уџбеника, Свјетлост.

Гиро 1964: Pierre Guiraud, Stlistika, prevod s francuskog Branko Džakula, Sarajevo: Veselin Masleša.

Eror 2002: G. Eror, Genetički vidovi interliterarnosti, Beograd: Otkrovenje.

Кајзер 1973: Вонфанг Кајзер, Језичко уметничко дело, превод с немачког Зоран Константиновић, Београд: СКЗ.

Ženet 1985: Ž. Ženet, Mimologije/ Put u Kratiliju, prevod sa francuskog Nada Vajs, Zagreb: GZH, BibliotekaTeka.

Живковић 2016: Д. Живковић, Отворени лавиринти: Еко и Павић, Крагујевац: ФИЛУМ. 
Еко 2001: U. Eko, Granice tumačenja, Beograd: Paideia.

Еко 2004: U. Eko, Kôd, prevela Mirjana Đukić - Vlahović, Beograd: Narodna knjiga, Alfa.

Јакобсон 1966: Roman Jakobson, Lingvistika i poetika, Beograd, Nolit, 1966.

Ковачевић 1988: М. Ковачевић, Узрочно семантичко поље, Сарајево: Свјетлост.

Ковачевић 1992: М. Ковачевић, Кроз синтагме и реченице, Сарајево: Свјетлост.

Ковачевић 1996: М. Ковачевић, Суштаствено и мимогредно у лингвистищи, Подгорица: Универзитет Црне Горе.

Ковачевић 1998а: М. Ковачевић, Синтакса сложене реченице у српском језику, Београд: Рашка школа, Србиње: Српско просвјетно и културно друштво Просвјета.

Ковачевић 1998б: Милош Ковачевић, Стилске фигуре и књижевни текст, Београд: Требник.

Ковачевић 1999: Милош Ковачевић, У одбрану језика српскога - $и$ даље, друго, допуњено издање, Београд: Требник.

Ковачевић 2000: Милош Ковачевић, Стилистика и граматика стилских фигура, Крагујевац: Кантакузин.

Ковачевић 2002: Милош Ковачевић, Синтаксичка негаџија у српскоме језику, Ниш: Универзитет у Нишу.

Ковачевић 2003а: Милош Ковачевић, Српски језик и српски језищи, Београд: БИГЗ, СКЗ.

Ковачевић 2003б: Милош Ковачевић, Граматичке и стилистичке теме, Бања Лука: Књижевна задруга.

Ковачевић 2005: Милош Ковачевић, Против неистина о српскоме језику, Источно Сарајево: СКПД Просвјета.

Ковачевић 2006: Милош Ковачевић, Списи о стилу и језику, Бања Лука: Књижевна задруга.

Ковачевић 2007: Милош Ковачевић, Србистичке теме, Крагујевац: ФИЛУМ, Београд: Кум.

Ковачевић 2008: Милош Ковачевић, Књижевни језик у Црној Гори између лингвистичких и политичких критеријума" у: Бранислав Остојић (ур.), Језичка ситуачија у Црној Гори - норма и стандардизаuзија, Подгорица: ЦАНУ, Научни скупови, Књига 87, Одјељење умјетности, књ. 29, 243-257. 
Ковачевић 2011: Милош Ковачевић, Стилска значења и зрачења, Ниш: Филозофски факултет.

Ковачевић 2011: Милош Ковачевић, Српски језик у вртлогу политике (у коауторству са Михаилом Шћепановићем), Подгорица: Матица српска - Друштво чланова у Црној Гори.

Ковачевић 2011: Милош Ковачевић, Граматичка питања српскога језика, Београд: Јасен, 2011.

Ковачевић 2012: Милош Ковачевић, Лингвосилистика књижевног текста, Београд: СКЗ.

Ковачевић 2015: Милош Ковачевић, О реченици и њеним члановима, Београд: Јасен.

Лотман 1976: Jurij Lotman, Struktura umetničkog teksta, prevod s ruskog Novica Petković, Beogard: Nolit.

Мајенова 2009: Marija Renata Majenova, Teorijska poetika, s poljskog prevela Biserka Rajčić, Beograd: Službeni glasnik.

Милосављевић 1985: Petar Milosavljević, Metodologija proučavanja književnosti, Novi Sad: Književna zajednica Novog Sada.

Мукаржовски 1987: Јан Мукаржовски, Структура, функиија, знак, вредност, Београд: Нолит.

Платон 2000: Platon, Kratil - Teetet, Sofist - Državnik, sa starogrčkog preveli Dinko Štambuk, Milivoj Sironić i Veljko Gortan, Beograd: Plato.

Pranjić 1968: Krunoslav Pranjić, Jezik i književno djelo (Ogledi za lingvostilističku analizu književnih tekstova), Zagreb: Školska knjiga.

Симић 2001: Радоје Симић, Општа стилистика, Београд, НДСЈ - Јасен.

Стојановић 2012: Бранко Стојановић, „Књижевно-научна симфонија”, предговор у: М. Ковачевић, Лингвосилистика књижевног текста, Београд: СКЗ, стр. 7-30.

Платон 2000: Platon, Kratil - Teetet, Sofist - Državnik, sa starogrčkog preveli: Dinko Štambuk, Milivoj Sironić i Veljko Gortan, Beograd: Plato.

Скот 1978: Klajv Skot, „Granice soneta”, Savremenik, god XXIV, knjiga XLVIII, sveska 10, Beograd, 318-329.

Шкловски 1991: Viktor Šklovski, Umetnost kao postupak, u: Teorijska misao o književnosti, priredio Petar Milosavljević, Novi Sad: Svetovi, 445-454. 


\title{
SCIENTIFIC IMPORTANCE AND DOMINANT INTERTEXTUAL ASPECTS OF LINGUO-STYLISTICS OF LITERARY TEXT BY MILOŠ KOVAČEVIĆ
}

\begin{abstract}
Summary
The subject of this paper is the analysis of the scientific importance and dominant intertextual aspects of the Linguistic Literature of the literary text of Miloš Kovacevic. The first part of the article is devoted to general aspects in the context of the relationship between world philological trends and srbistics: from the immanent features of Kovačević's scientific mission, through the influence, structure of methodological procedures and interpretative attitudes, dominant intertextual relationships, upgrading the philological tradition. The second part of the paper is devoted to the special aspects of Kovačević's texts and their relations, original scientific attitudes, changes in linguistic perception and arguable defense of the stylistic procedures of significant authors of Serbian literature. Kovačević's analysis and synthesis of stylistic dominants was accomplished in order to preserve and enhance the historical and contemporary values of Serbian literature and culture.

In addition to these scientific contributions as a guideline for future philological trends in Serbia, we emphasize Kovacevic's defense of the identity of the Serbian language in order to preserve the awareness of the uniqueness and originality of the Serbian language and Serbian identity in general. Kovačević's scientific mission represents the defense of the dignity of entire Serbian philology.

Keywords: Miloš Kovačević, scientific importance, intertextual aspects, Linguo-stylistics, Serbistics, stylematicity, stylogenity.
\end{abstract}

